\title{
EUROPEAN FUNDS AND AIR SERVICES MARKET IN POLAND
}

\author{
ANNA KATARZYNA MAZUREK-KUSIAK \\ University of Life Sciences in Lublin, Department Tourism and Recreation, POLAND \\ e-mail: anna.mazurek@up.lublin.pl
}

\begin{tabular}{l|l} 
RECEIVED & 18 January 2018 \\
ACCEPTED & 2 September 2018 \\
JEL & \\
CLASSIFICATION & L11, L83, L93
\end{tabular}

KEYWORDS airports, passenger traffic, European Funds

ABSTRACT The aim of the study was to analyze the investments made in the air transport sector in Poland financed by the EU programs against the dynamics of the number of passengers served by Polish airports. Secondary studies were conducted by means of statistical data analysis from airports in Poland, the European Union funds and analysis of annual reports on implementation of Regional Operational Programs of individual provinces in Poland as well as CUPT reports. The value of expenditures incurred for the execution of investments at airports in Poland by 2015 is PLN 5.6 billion, of which the total value of funds granted by the EU amounts to nearly PLN 2.2 billion, of which PLN 1.6 billion under the OPI\&E and almost PLN 600 million from Regional Operational Programs. Due to the investments made at airports, the dynamics of air transport has increased. In 2008, Polish airports served over 20 million passengers, and in 2016 almost 34 million, i.e. $64.75 \%$ more than in the base year, as a result of which the competitiveness of Polish air transport increased due to the greater choice of connections, lower prices, greater security, better integration of airports with railway lines and road transport.

\section{Introduction}

The process of globalization encompasses increasingly large areas and becomes an impulse that influences on the development of aviation, economy and growing market expansion of the participating entities. Taking on ever greater share of the international economic space becomes economically viable, as it makes it possible to obtain disproportionately higher profits from global market participation than local one (Hawlena, 2012a, p. 15). 
Development of the aviation service market is one of the key factors of globalization and development of global economy, and it also has a huge impact on the volume of tourism. The Polish air services market is part of the European and global transport system (Panfiluk, 2017, pp. 540-547). Dynamic changes in this market took place after Poland's accession to the European Union, due to which investments in the construction and development of communication systems, airports, and higher levels of passenger safety were possible. This, in turn, attracts tourists with different social status and different preferences (Tłoczyński, 2016a, p. 28).

As a result of deregulation and liberalization of the transport market as well as integration transformations, there have been significant changes in the socio-economic systems of many countries and regions, which played a significant role in the civil air transport (Hawlena, Mazurek-Kusiak, Wojciechowska-Solis, 2015, pp. 3639-3647). The rate of society development has become increasingly dependent on the level of air transportation. Due to this, it was possible to quickly reach more and more distant regions of the world, accelerating the activation of areas covered by the network of connections (Hawlena, 2012b, p. 41). Aviation has become a significant factor in global growth, trade, tourism and people-to-people contacts, as it has enabled time and space compression unprecedented in other transport branches (Panasiuk, 2012, p. 51). Being one of the most important instruments of globalization, it largely determines the dynamics of this process, and thus the economic development of the world (Hawlena, 2012b, p. 41).

Processes taking place in the global aviation market interweave and complement the activities and processes within the European aviation area. Growing strength of global aviation groups and liberalization pose new challenges to transport policy in regulating, modeling and monitoring the market, while ensuring its sustainable development. Poland's accession to the European Community and the inclusion of Polish aviation in EU structures has changed the conditions of the aviation sector in Poland (Walczak-Beszczyńska et al., 2010, pp. 200-211).

The rapid development of air services in Poland required large investments at airports that wanted to meet the demands of competition and become a reality in the European market, because at the beginning of the 21st century, Polish airports were characterized by low capacity due to underinvestment. The main problem in the development of this market was to procure the necessary capital to realize the necessary investments. However, while financing the investments and building new airports, their profitability deteriorated, so that not every port was attractive to potential investors. The EU Structural Funds, which are primarily aimed at entering the non-EU markets, developing fair competition, increasing capacity, improving service quality, maintaining a high standard of safety in air transport, are a considerable help in such situation (Tomova, 2016, pp. 81-87).

\section{Purpose and research methods}

The aim of the study was to analyze the investments made in the air transport sector in Poland financed by the EU programs against the dynamics of the number of passengers served by Polish airports.

Secondary studies were conducted by means of statistical data analysis (dynamics, chain growth, one-step increment, the mobility factor of Polish citizens) from airports in Bydgoszcz, Gdańsk, Katowice, Cracow, Lublin, Łódź, Modlin, Olsztyn, Poznań, Rzeszów, Szczecin, Wrocław, Warsaw, Zielona Góra, i.e. ports using the European Union funds and analysis of annual reports on implementation of Regional Operational Programs of individual provinces in Poland as well as CUPT reports (Centre for EU Transport Projects). The statistical and financial data refer to years 2007-2016. 


\section{Results and discussion}

With the development of competition, airports are implementing a number of investment programs designed to increase airport capacity, while ensuring the greatest possible security of air operations and ensuring the sustainable development of air transport (Halpern, Graham, 2015, pp. 213-221). Airports included in the TEN-T (Trans-European Transport Networks), i.e. ports: Bydgoszcz, Gdańsk, Katowice, Cracow, Łódź, Poznań, Rzeszów, Szczecin, Wrocław, Warsaw, carry out investments co-financed by the European Union budget under the Infrastructure and Environment Program 2007-2013 (OPI\&E), the TEN-T Community Program and 16 regional programs for 2007-2013. Other airports, that are not affiliated to the TEN-T network, are investing within regional programs.

Table 1. Value in PLN of EU co-financing for individual airports in Poland in 2007-2015

\begin{tabular}{lccc}
\hline \multicolumn{1}{c}{ Airport } & Value of the whole project & EU co-financing & \% of co-financing \\
\hline Bydgoszcz & $71,000,000.00$ & $54,500,000.00$ & 76.76 \\
Gdańsk & $505,471,512.28$ & $211,362,972.09$ & 41.82 \\
Katowice & $434,385,371.51$ & $172,626,931.39$ & 39.74 \\
Kraków & $724,770,695.22$ & $298,296,580.43$ & 41.16 \\
Lublin & $342,328,134.54$ & $93,750,000.00$ & 27.39 \\
Łódź & $208,371,021.03$ & $109,209,360.23$ & 52.41 \\
Modlin & $424,399,809.59$ & $142,126,590.40$ & 33.49 \\
Olsztyn & $205,368,085.00$ & $120,393,493.61$ & 58.62 \\
Poznań & $258,120,526.51$ & $104,917,623.41$ & 40.65 \\
Rzeszów & $417,829,817.43$ & $202,994,970.27$ & 48.58 \\
Szczecin & $144,449,631.44$ & $60,032,282.97$ & 41.56 \\
Warszawa & $1,444,263,636.11$ & $489,331,885.07$ & 33.88 \\
Wrocław & $533,607,450.16$ & $185,495,642.26$ & 34.76 \\
Zielona Góra & $5,800,000.00$ & $4,900,000.00$ & 84.48 \\
\hline Total & $5,649,165,690.82$ & $2,195,438,332.13$ & 38.86 \\
\hline
\end{tabular}

Source: own study based on annual reports on implementation of Regional Operational Programs, CUIT reports, www.cupt.gov.pl, http://mib. gov.pl, https://www.funduszeeuropejskie.gov.pl (2017).

The value of expenditures incurred for the execution of investments at airports by 2015 is over PLN 5.6 billion, of which the total value of funds granted by the EU amounts to almost PLN 2.2 billion, of which PLN 1.6 billion was allocated under the POli and almost PLN 600 million from Regional Operational Programs (http://mib.gov.pl). These investments contribute to the development of the so-called catchment area and increased demand for air transport services (Suau-Sanchez, Voltes-Dorta, Rodirguez-Deniz, 2015, pp. 157-166). Also investment in the construction of new airports is important, because they can provide significant opportunities for economic development in smaller cities (Wittman, 2014, pp. 220-228) such as Rzeszów, Lublin or Zielona Góra.

On the basis of the data presented in Table 1, it can be noted that the largest co-financing in 2007-2015 was received by the airport in Warsaw (over PLN 489 million), Cracow (over PLN 298 million) and Gdańsk (over PLN 211 million). On the other hand, while looking at the \% of financing the investment by means of the EU budget, the airports in Zielona Góra (84.48\% of the co-financing for the investments carried out), Bydgoszcz (76.76\%), Olsztyn (58.62\%) and in Łódź (52.41\%), were the most favorable. 


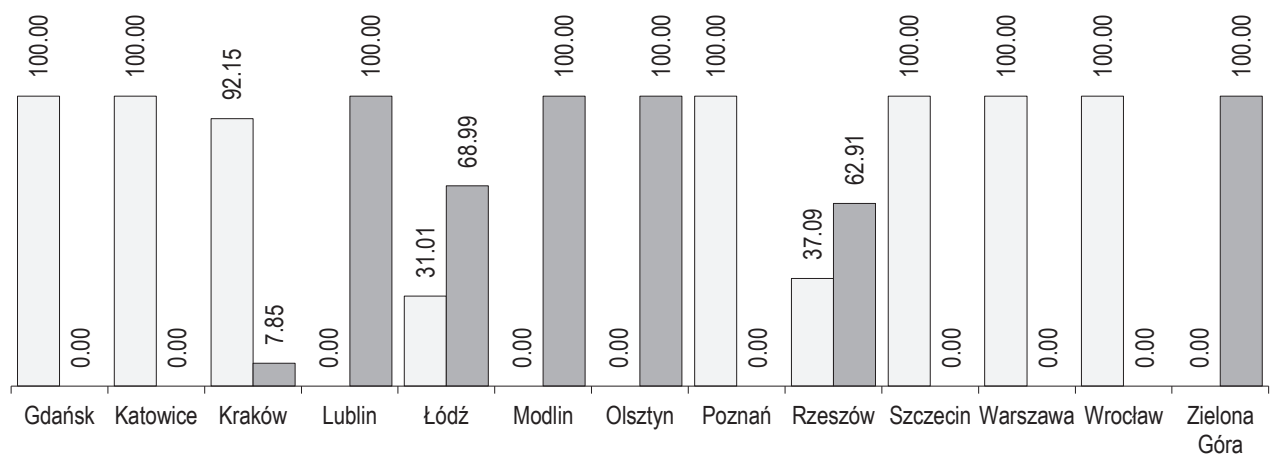

$\square$ Funding for the Infrastructure and Environment Program and the TEN-T Program $\quad \square$ Co-financing from the ROP

Figure 1. Types of programs in financing investments in airports in Poland in 2007-2015

Source: own study based on annual reports on implementation of Regional Operational Programs, CUIT reports, www.cupt.gov.pl, http://mib. gov.pl, https://www.funduszeeuropejskie.gov.pl (2017).

Investments at airports in Lublin, Modlin, Olsztyn and Zielona Góra have been co-financed only by the Regional Operational Program, whereas investments at airports in Gdańsk, Katowice, Poznań, Szczecin, Warsaw and Wrockaw have been financed by the Infrastructure and Environment Program and the TEN-T program. The airports of Cracow, Łódź and Rzeszów were supported by the Regional Operational Program as well as the Infrastructure and Environment Program and the TEN-T program. It can be seen from the data presented in Figure 1 that the affiliation of airports to the TEN-T network also means access to more aid under the Infrastructure and Environment Operational Program. These ports can also benefit from regional programs Airports outside the TEN-T network, for which Regional Operational Programs remain the only sources of EU grants, have not be considered by the national program at all (Walewski, Gościniarek, Czura, 2010). These programs provide grants for regional airports, among others, in provinces: Lubelskie (modernization and expansion of the airport in Świdnik), Łódzkie (airport in Lublinek), Masovian (Modlin airport), Warmia-Mazurian (airport in Olsztyn).

From the budget of the Cohesion Policy for 2014-2020, Poland will receive $€ 82.5$ billion, of which $€ 4.1$ billion will be infrastructure projects of European significance in the field of transport under the Connecting Europe instrument, of which some of the airport's financial resources has been already developed. Between 2014 and 2020 , the regional authorities will manage about $40 \%$ of cohesion policy funds $-€ 31.28$ billion (Tłoczyński, $2016 \mathrm{~b}$, pp. 408-414). The funds will be distributed through regional operational programs. Regional programs will be funded by the European Regional Development Fund and the European Social Fund. The amounts allocated to individual provinces are shown in Figure 2.

According to Walewski et al. (2010), it should be noted that in addition to funding from the European Structural Funds, some airports received investment grants from the central budget. The presented picture of available sources of financing investment at airports seems to be a favorable development prospect for Polish airports. It is worth remembering, however, that the availability of funds is also determined by the financial or credit capacity of the airports themselves. While larger airports do not have any problems in this area, the less prosperous ones are experiencing financial difficulties with the project. 


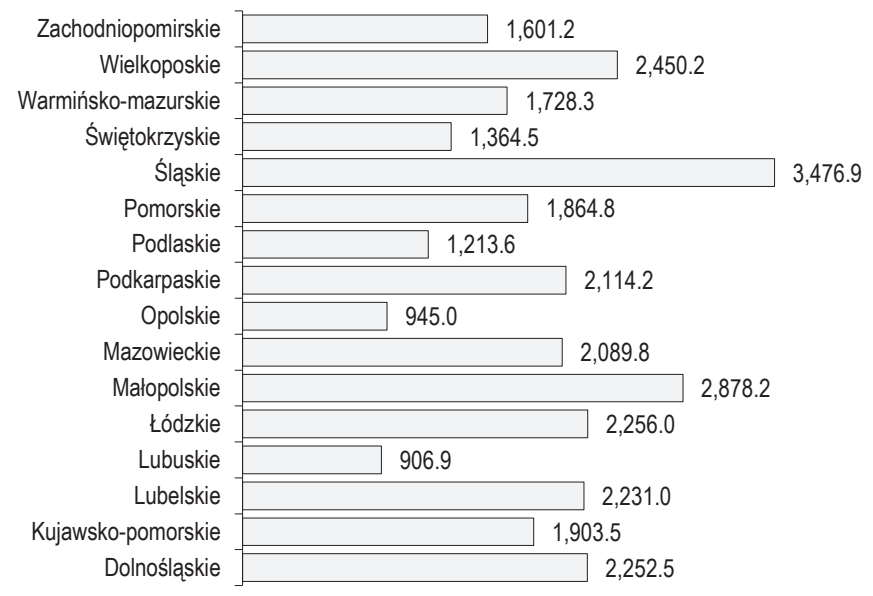

Figure 2. European funds for Polish regions for 2014-2020

Source: Ministry of Infrastructure and Development, www.mir.gov.pl (2017).

The investments made in air transport using EU funds are designed to stimulate the economy, strengthen the EU's position in the global market. Research carried out by Tłoczyński (2016a, p. 28) shows that as a result of the investment, the competitiveness of Polish air transport has increased, which may make better use of the transformation of the world economy.

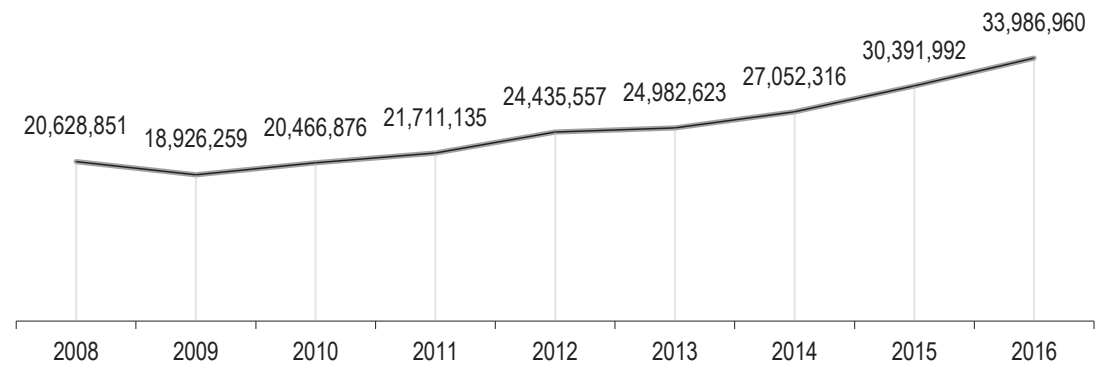

Figure 3. Number of passengers served by Polish airports in 2008-2016

Source: own study on the basis of information obtained from airports, ULC Warsaw, 2010-2017.

In 2008, Polish airports served more than 20 million passengers, in 2009 it was $8.28 \%$ less. Since 2010, the number of served passengers has been increasing steadily, reaching nearly 34 million in 2016, i.e. by $11.83 \%$ more than in the previous year. As compared to 2008 , the number of served passengers increased by $64.75 \%$. The exact number of passengers served and the dynamics of tourist traffic at airports are shown in Figure 3 and Table 2. 
Table 2. Dynamics of tourist traffic at Polish airports in 2008-2016

\begin{tabular}{lccccccccc}
\cline { 2 - 9 } & 2008 & 2009 & 2010 & 2011 & 2012 & 2013 & 2014 & 2015 & 2016 \\
\hline Dynamics $\mathrm{t}_{0}=\mathrm{t}_{\mathrm{n}-1}$ & 0 & -8.25 & 8.14 & 6.08 & 12.55 & 2.24 & 8.28 & 12.35 & 11.83 \\
Dynamics $\mathrm{t}_{\mathrm{n}}=2008$ & 0 & -8.25 & -0.79 & 5.25 & 18.45 & 21.11 & 31.14 & 47.33 & 64.75 \\
\hline
\end{tabular}

Source: own study on the basis of information obtained from airports, ULC Warsaw, 2010-2017.

Studies performed by Walczak-Beszczyńska et al. (2010, pp. 200-211) indicate that in 2004, dynamics of air transport has significantly increased as a result of market liberalization, economic growth and regional airport management in attracting low cost operators. At the same time, there were problems of Polish air transport, which resulted mainly from insufficient funds for development and modernization of regional ports, problems with applying for co-financing, which led to the fact that the EU funds were not fully utilized. In addition, the brake on the development of this transport sector was primarily: low awareness of local communities about the importance of airlines for regional development, lack of coherence of road and rail infrastructure with aeronautical infrastructure development programs.

Table 3. Number of passengers served by selected Polish airports in 2008-2016

\begin{tabular}{|c|c|c|c|c|c|c|c|c|c|}
\hline & 2008 & 2009 & 2010 & 2011 & 2012 & 2013 & 2014 & 2015 & 2016 \\
\hline Airport & & & & & Bydgoszcz & & & & \\
\hline $\begin{array}{l}\text { Number of served } \\
\text { passengers }\end{array}$ & 266,982 & 264,529 & 266,480 & 268,360 & 328,099 & 330,658 & 268,420 & 318,817 & 322,135 \\
\hline Chain growth & - & -0.92 & 0.74 & 0.71 & 22.26 & 0.78 & -18.82 & 18.78 & 1.04 \\
\hline $\begin{array}{l}\text { One-step increment } \\
t_{0}=2008\end{array}$ & 0 & -0.92 & -0.19 & 0.52 & 22.89 & 23.85 & 0.54 & 19.42 & 20.66 \\
\hline Airport & & & & & Gdańsk & & & & \\
\hline $\begin{array}{l}\text { Number of served } \\
\text { passengers }\end{array}$ & $1,930,513$ & $1,890,253$ & $2,208,819$ & $2,449,702$ & $2,861,774$ & $2,826,412$ & $3,238,064$ & $3,676,771$ & $3,966,655$ \\
\hline Chain growth & - & -2.09 & 16.85 & 10.91 & 16.82 & -1.24 & 14.56 & 13.55 & 7.88 \\
\hline $\begin{array}{l}\text { One-step increment } \\
\mathrm{t}_{0}=2008\end{array}$ & 0 & -2.09 & 14.42 & 26.89 & 48.24 & 46.41 & 67.73 & 90.46 & 105.47 \\
\hline Airport & & & & & Katowice & & & & \\
\hline $\begin{array}{l}\text { Number of served } \\
\text { passengers }\end{array}$ & $2,402,338$ & $2,301,161$ & $2,366,410$ & $2,500,984$ & $2,518,409$ & $2,506,694$ & $2,668,421$ & $3,044,017$ & $3,201,654$ \\
\hline Chain growth & - & -4.21 & 2.84 & 5.69 & 0.70 & -0.47 & 6.45 & 14.08 & 5.18 \\
\hline $\begin{array}{l}\text { One-step increment } \\
t_{0}=2008\end{array}$ & 0 & -4.21 & -1.50 & 4.11 & 4.83 & 4.34 & 11.08 & 26.71 & 33.27 \\
\hline Airport & & & & & Kraków & & & & \\
\hline $\begin{array}{l}\text { Number of served } \\
\text { passengers }\end{array}$ & $2,897,071$ & $2,658,841$ & $2,839,124$ & $2,994,359$ & $3,408,954$ & $3,636,804$ & $3,806,801$ & $4,208,661$ & $4,974,676$ \\
\hline Chain growth & - & -8.22 & 6.78 & 5.47 & 13.85 & 6.68 & 4.67 & 10.56 & 18.20 \\
\hline $\begin{array}{l}\text { One-step increment } \\
t_{0}=2008\end{array}$ & 0 & -8.22 & -2.00 & 3.36 & 17.67 & 25.53 & 31.40 & 45.27 & 71.71 \\
\hline Airport & & & & & Lublin & & & & \\
\hline $\begin{array}{l}\text { Number of served } \\
\text { passengers }\end{array}$ & & & & & 5,697 & 188,723 & 184,876 & 264,070 & 376,755 \\
\hline Chain growth & & & & & - & - & -2.04 & 42.84 & 42.67 \\
\hline $\begin{array}{l}\text { One-step increment } \\
t_{0}=2013^{*}\end{array}$ & & & & & - & 0 & -2.04 & 39.92 & 99.63 \\
\hline
\end{tabular}




\begin{tabular}{|c|c|c|c|c|c|c|c|c|c|}
\hline Airport & & & & & Łódź & & & & \\
\hline $\begin{array}{l}\text { Number of served } \\
\text { passengers }\end{array}$ & 341,788 & 312,197 & 413,392 & 390,261 & 463,459 & 353,633 & 253,376 & 287,620 & 241,256 \\
\hline Chain growth & - & -8.66 & 32.41 & -5.60 & 18.76 & -23.70 & -28.35 & 13.52 & -16.12 \\
\hline $\begin{array}{l}\text { One-step increment } \\
t_{0}=2008\end{array}$ & 0 & -8.66 & 20.95 & 14.18 & 35.60 & 3.47 & -25.87 & -15.85 & -29.41 \\
\hline Airport & & & & & Modlin & & & & \\
\hline $\begin{array}{l}\text { Number of served } \\
\text { passengers }\end{array}$ & & & & & 857,481 & 344,566 & $1,703,743$ & $2,589,286$ & $2,859,191$ \\
\hline Chain growth & & & & & - & -59.82 & 394.46 & 51.98 & 10.42 \\
\hline $\begin{array}{l}\text { One-step increment } \\
t_{0}=2012\end{array}$ & & & & & 0 & -59.82 & 98.69 & 201.96 & 233.44 \\
\hline Airport & & & & & Poznań & & & & \\
\hline $\begin{array}{l}\text { Number of served } \\
\text { passengers }\end{array}$ & $1,256,064$ & $1,235,942$ & $1,383,656$ & $1,425,865$ & $1,560,334$ & $1,329,331$ & $1,423,019$ & $1,477,318$ & $1,689,200$ \\
\hline Chain growth & - & -1.60 & 11.95 & 3.05 & 9.43 & -14.80 & 7.05 & 3.82 & 14.34 \\
\hline $\begin{array}{l}\text { One-step increment } \\
t_{0}=2008\end{array}$ & 0 & -1.60 & 10.16 & 13.52 & 24.22 & 5.83 & 13.29 & 17.61 & 34.48 \\
\hline Airport & & & & & Rzeszów & & & & \\
\hline $\begin{array}{l}\text { Number of served } \\
\text { passengers }\end{array}$ & 320,115 & 380,711 & 451,720 & 487,740 & 562,934 & 588,148 & 599,483 & 641,146 & 662,024 \\
\hline Chain growth & - & 18.93 & 18.65 & 7.97 & 15.42 & 4.48 & 1.93 & 6.95 & 3.26 \\
\hline $\begin{array}{l}\text { One-step increment } \\
t_{0}=2008\end{array}$ & 0 & 18.93 & 41.11 & 52.36 & 75.85 & 83.73 & 87.27 & 100.29 & 106.81 \\
\hline Airport & & & & & Szczecin & & & & \\
\hline $\begin{array}{l}\text { Number of served } \\
\text { passengers }\end{array}$ & 293,884 & 276,582 & 268,563 & 258,217 & 347,063 & 322,334 & 286,377 & 412,162 & 467,437 \\
\hline Chain growth & - & -5.89 & -2.90 & -3.85 & 34.41 & -7.13 & -11.16 & 43.92 & 13.41 \\
\hline $\begin{array}{l}\text { One-step increment } \\
t_{0}=2008\end{array}$ & 0 & -5.89 & -8.62 & -12.14 & 18.10 & 9.68 & -2.55 & 40.25 & 59.05 \\
\hline Airport & & & & & Warszawa & & & & \\
\hline $\begin{array}{l}\text { Number of served } \\
\text { passengers }\end{array}$ & $9,436,958$ & $8,278,747$ & $8,666,552$ & $9,322,485$ & $9,567,063$ & $10,669,879$ & $10,574,539$ & $11,186,688$ & $12,795,356$ \\
\hline Chain growth & - & -12.27 & 4.68 & 7.57 & 2.62 & 11.53 & -0.89 & 5.79 & 14.38 \\
\hline $\begin{array}{l}\text { One-step increment } \\
t_{0}=2008\end{array}$ & 0 & -12.27 & -8.16 & -1.21 & 1.38 & 13.06 & 12.05 & 18.54 & 35.59 \\
\hline Airport & & & & & Wrocław & & & & \\
\hline $\begin{array}{l}\text { Number of served } \\
\text { passengers }\end{array}$ & $1,477,901$ & $1,324,483$ & $1,598,533$ & $1,606,222$ & $1,942,000$ & $1,873,245$ & $2,034,515$ & $2,269,216$ & $2,371,621$ \\
\hline Chain growth & - & -10.38 & 20.69 & 0.48 & 20.90 & -3.54 & 8.61 & 11.54 & 4.51 \\
\hline $\begin{array}{l}\text { One-step increment } \\
t_{0}=2008\end{array}$ & 0 & -10.38 & 8.16 & 8.68 & 31.40 & 26.75 & 37.66 & 53.54 & 60.47 \\
\hline Airport & & & & & Zielona,Góra & & & & \\
\hline $\begin{array}{l}\text { Number of served } \\
\text { passengers }\end{array}$ & 5,237 & 2,813 & 3,627 & 6,940 & 12,290 & 12,196 & 10,682 & 15,550 & 8,745 \\
\hline Chain growth & - & -46.29 & 28.94 & 91.34 & 77.09 & -0.76 & -12.41 & 45.57 & -43.76 \\
\hline $\begin{array}{l}\text { One-step increment } \\
t_{0}=2008\end{array}$ & 0 & -46.29 & -30.74 & 32.52 & 134.68 & 132.88 & 103.97 & 196.93 & 66.98 \\
\hline
\end{tabular}

*The airport in Lublin started its activity in December 2012.

Source: own study on the basis of information obtained from airports, ULC Warsaw, 2010-2017. 
It should also be noted that Poland's participation in international air traffic is marginal. According to Eurostat data, this share was 0.653 in 2004and it increased only four times to 2.692 in 10 years. Low level of Poland's participation in international air traffic results, among others, from low mobility factor of passengers in air transport (Figure 4). The mobility factor informs how many times an average citizen has used the air transport (Taylor, Ciechańska, 2015, pp. 255-278).

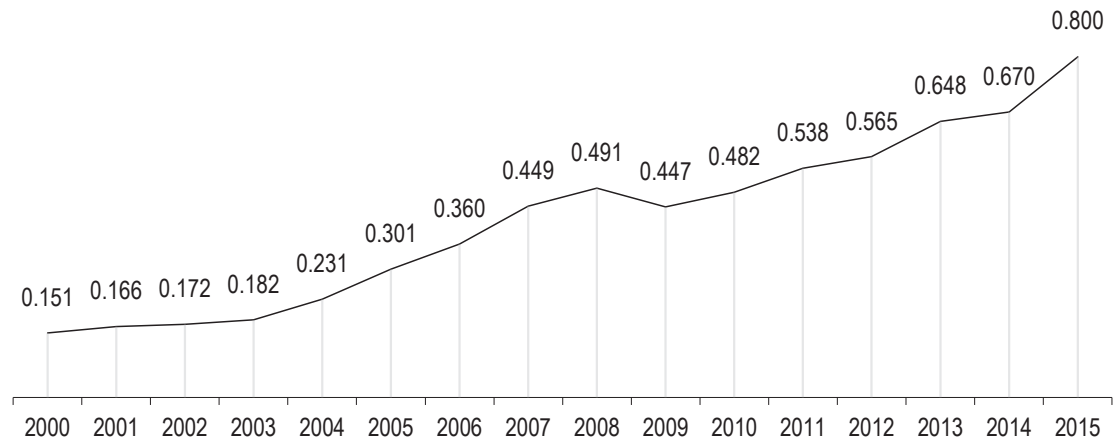

Figure 4. The mobility factor of Polish citizens in air transport in 2010-2015

Source: own study based on Eurostat data.

It is a positive phenomenon that the rate of air travel of Poles is growing year by year, from 0.151 in 2000 to 0.800 in 2015, as shown in Figure 4.

The increase in the mobility factor is mainly due to the increase in the mobility of Poles, the improvement of the financial situation, introduction of low cost airline services and the resulting competitiveness of flights as compared to other modes of transport. Responding to the growing demand for air services, ports are forced to conduct a number of activities to increase the availability of air services, to increase the range of services offered, to improve the quality of their services, to pursue a flexible pricing policy aimed at increasing the competitiveness of their services (Tłoczyński, 2016b, p. 28).

\section{Conclusions}

1. Air transport is one of the most important activities of European and global economy, which is essential both for the economic development and the progress of integration processes.

2. Airports included in the TEN-T network have implemented investments co-financed by the EU budget under the Infrastructure and Environment Program, the Community Program and 16 regional programs for 2007-2013. Other airports not belonging to the TEN-T network could only invest within regional programs. On the other hand, for the years 2014-2020 Poland received about $€ 4.1$ billion for infrastructure projects of European importance in the field of transport from the cohesion policy budget, and regional authorities will be able to manage about $€ 31.28$ billion from the cohesion policy fund. However, it must be remembered that the availability of funds is also determined by the financial and credit capacities of the airports themselves. 
3. The value of expenditures incurred for the execution of investments at airports in Poland by 2015 is PLN 5.6 billion, of which the total value of funds granted by the EU amounts to nearly PLN 2.2 billion, of which PLN 1.6 billion under the OPI\&E and almost PLN 600 million from Regional Operational Programs.

4. Due to the investments made at airports, the dynamics of air transport has increased. In 2008, Polish airports served over 20 million passengers, and in 2016 almost 34 million, i.e. $64.75 \%$ more than in the base year, as a result of which the competitiveness of Polish air transport increased due to the greater choice of connections, lower prices, greater security, better integration of airports with railway lines and road transport.

\section{References}

Halpern, N., Graham, A. (2015). Airport route development: A survey of current practice. Tourism Management, 46, $213-221$.

Hawlena, J. (2012a). Konkurencja na rynku lotniczych przewozów pasażerskich w warunkach globalizacji. Katowice: Prace Naukowe Uniwersytetu Ekonomicznego w Katowicach.

Hawlena, J. (2012b). Rynek niskokosztowych przewozów lotniczych a rozwój sektora turystyki. Radom: Instytut Naukowo-Wydawniczy „Spatium”.

Hawlena, J., Mazurek-Kusiak, A., Wojciechowska-Solis, J. (2015). Wide-body aircraft in service of tourist traffic. Logistyka, 4, 3639-3647.

Panasiuk, A. (2012). Ekonomika turystyki i rekreacji. Warszawa: Wydawnictwo Naukowe PWN.

Panfiluk, E. (2017). Analyses of the effectiveness the European Regional Development Found Disbursement for the selected Tourism services with the Use of the Counterfactual Method. Procedia Engineering, 182, 540-547.

Sprawozdania CUIT za lata 2007-2015.

Suau-Sanchez, P., Voltes-Dorta, A., Rodirguez-Deniz, H. (2015). Regulatory airport classification in the US: The role of international markets. Transport Policy, 37, 157-166.

Taylor, Z., Ciechański, A. (2015). Transport lotniczy w obsłudze polskich turoperatorów. Przegląd Geograficzny, 87 (2), $255-278$.

Tłoczyński, D. (2016a). Raport. Rynek Lotniczy 2016. Warszawa: Eurosystem.

Tłoczyński, D. (2016b). Development Policy of Warsaw Chopin Airport in the Light of the European Funds for 2014-2020. Procedia Engineering, 134, 408-414.

Tomova, A. (2016). Are commercial revenues important to today's European air navigation services providers? Journal of air Transport Management, 54, 81-87.

Walczak-Beszczyńska, A., Barczak, M., Saks, E., Marszańska, M., Wilmańska, K. (2010). Analiza pasażerskiego rynku transportu lotniczego w Polsce w latach 2004-2009, ze szczególnym uwzględnieniem pasażerskich połączeń z Portu Lotniczego im. I. Paderewskiego w Bydgoszczy. In: W. Żukow, R. Muszkieta, M. Napierała, M. Barczak (eds.), Stan i rozwój regionalnej turystyki, rekreacji i rehabilitacji (pp. 200-211). Bydgoszcz: Perfekt Gaul.

Walewski, P., Gościniarek, S., Czura, M. (2010). Fundusze unijne na rozbudowę portów lotniczych. Retrieved from: https://www.log24. pl/artykuly/fundusze-unijne-na-rozbudowe-portow-lotniczych,74.

Wittman, M.D. (2014). Public funding of airport incentives in the United states: The efficacy of the small community air services development grant program. Transport Policy, 35, 220-228.

www.cupt.gov.pl.

www.eurostat.com.

www.funduszeeuropejskie.gov.pl.

www.mib.gov.pl.

www.mir.gov.pl.

Cite this apticle aS: Mazurek-Kusiak, A.K. (2018). European funds and air services market in Poland. European Journal of Service Management, 3 (27/2), 271-279. DOI: 10.18276/ejsm.2018.27/2-33. 